\title{
Eimeria nebulosa n. sp. and Klossia pachyleparon n. sp. from the monitor lizard Varanus nebulosus in Malaysia
}

\author{
by F. C. COLLEY and J. G. ELSE \\ Institute for Medical Research, Kuala Lumpur \\ and the G.W. Hooper Foundation, University of California, \\ San Francisco, California 94143, U.S.A.
}

\section{Summary.}

Eimeria nebulosa n. sp. and Klossia pachyleparon n. sp. are described from the monitor lizard Varanus nebulosus in Malaysia. The flask shaped oocysts of E. nebulosa average 20.7 by $12.6 \mu \mathrm{m}$. The oocyst wall is composed of a single layer. There is a single polar granule but no residuum. Ellipsoidal sporocysts average 11.1 by $5.6 \mu \mathrm{m}$. A sporocyst residuum is present. Endogenous stages develop in the epithelial cells of the small intestine. The spherical oocysts of $K$. pachyleparon average $33.6 \mu \mathrm{m}$ in diameter. The wall is about $2.5 \mu \mathrm{m}$ thick and is composed of 3 layers. The spherical sporocysts average $10.8 \mu \mathrm{m}$ in diameter. Sporocysts contain 4 sporozoites and residuum. Developmental stages were not observed.

\section{Résumé.}

Eimeria nebulosa n. sp. et Klossia pachyleparon n. sp. parasites du varan Varanus nebulosus en Malaisie.

Eimeria nebulosa n. sp. et Klossia pachyleparon n. sp. sont décrites chez le varan Varanus nebulosus en Malaisie. Les oocystes d'E. nebulosa, de forme ovoïde avec un pôle conique, mesurent en moyenne $20,7 \mu \times 12,6 \mu$. La paroi de 1'oocyste est simple. Celui-ci contient un granule polaire unique et pas de résidu oocystique. Les sporocystes ellipsoïdaux

Supported by the University of California International Center for Medical Research (UC ICMR, Hooper Foundation, University of California, San Francisco 94143) with research grant AI 10051 to the Department of International Heaith, School of Medicine, University of California, San Francisco, from the National Institute of Allergy and Infectious Diseases, National Institutes of Health, U.S. Public Health Service.

Requests for reprints should be sent to the G. W. Hooper Foundation, San Francisco. 
mesurent en moyenne $11,1 \mu \times 5,6 \mu$. et contiennent un résidu sporocystique. Les formes de multiplication se développent dans les cellules épithéliales de l'intestin grêle. Les oocystes sphériques de $K$. pachyleparon ont un diamètre moyen de $33,6 \mu$. Leur paroi, épaisse de $2,5 \mu$, est formée par 3 enveloppes. Les sporocystes sphériques ont un diamètre moyen de $10,8 \mu$. Ils contiennent 4 sporozoïtes et un résidu sporocystique. Les formes tissulaires n'ont pas été observées.

During a survey of parasites of Malaysian reptiles one of 7 monitor lizards (Varanus nebulosus) were found to be infected with an Eimeria species and one with Eimeria and Klossia species. The sporulated oocysts and endogenous stages are described here.

\section{Materials and Methods}

Feces containing coccidial oocysts were crushed and placed in a thin layer of $2,5 \%$ potassium dichromate solution in a petri dish. Oocysts were allowed to sporulate 1 week at room temperature (approximately $30 \mathrm{C}$ ) and the stored at 4 C until examination.

After sugar flotation, the sporulated oocysts were studied a Leitz Ortholux microscope with apochromatic objectives and measured with an ocular micrometer. The composite drawing is based on freehand sketches and photomicrographs. Measurements are in micrometers. The range is followed by the mean in parentheses.

The lizard positive for Eimeria and Klossia spp. was killed and impression smears were made from the small and large intestine, liver, lungs, kidney, spleen and brain. Smears were fixed with absolute methanol and stained with Giemsa. Additional tissue from the alimentary tracts was fixed in Carnoy, embedded in paraffin and sectioned. Slides were stained with collophonium-Giemsa.

\section{Results}

\section{Eimeria nebulosa n. sp.}

Description of oocysts (fig. 1, 5). Oocysts ellipsoidal with a constriction at one end so that the overall shape is flask-like. Oocyst wall smooth composed of a single yellowish layer, approximately, $1 \mu \mathrm{m}$ thick. No micropyle. Thirty sporulated oocysts 19-23 by $11-14$ um (20.7 by 12.6). Length-width ratios $1.5-1.8$ (1.64). Sporulated oocyst with a single polar granule but no residuum. 
Sporocysts ellipsoidal to slightly ovoid. Stieda body absent. Twenty five sporocysts $10-13$ by $5-6 \mu \mathrm{m}$ (11.1 by 5.6$)$. Lengthwidth ratios 1.8-2.3 (1.96). Sporocyst residuum coarsely granular. Sporozoites commashaped, lying lengthwise "head to tail" in sporocysts. A refractile globule is present at each end of the sporozoite.

Endogenous stages. All endogenous stages were in epithelial cells of the small intestine. Heaviest infection was seen in the duodenum. Trophozoites 3-5 $\mu \mathrm{m}$ in diameter were seen above the host cell nuclei (fig. 2). Schizonts 5-7 $\mu \mathrm{m}$ in diameter were also observed (fig. 3). Schizonts had up to 12 nuclei. Micro and macrogametrocytes 7-12 $\mu \mathrm{m}$ in diameter were observed above or beside host cell nuclei (fig. 4).

Remarks. The shape of the oocyst of E. nubulosa is markedly different from all other Eimeria species described from lizards to date (Pellerdy, 1965, 1969; Bovee and Telford, 1965; and Cannon, 1969). The only other lizard eimerian with flask-shaped oocysts is $E$. hemadactyli from the gekko Hemadactylus flavaridis (Knowles and Das

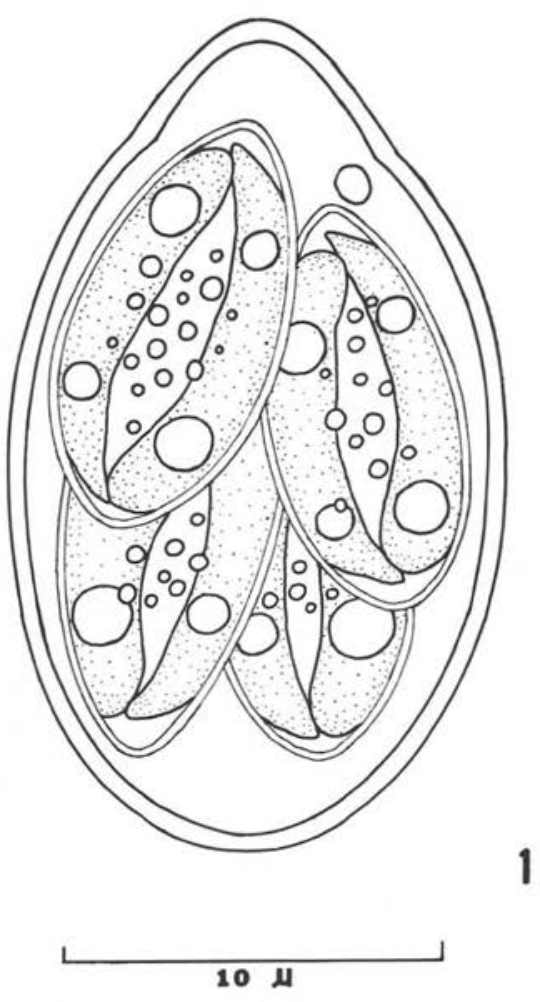

FIg. 1. - Sporulated oocyst of Eimeria nebulosa sp. $\mathrm{n}$. Gupta, 1935).

The oocyst of $E$. nebulosa differs from that of $E$. hemadactyli as follows. In having an average length-width ratio of 1.64 rather than 1.23 and in having more elongate sporocysts with an average length-width ratio of 1.96 rather than 1.5 .

On the basis of host and morphological differences we feel that E. nebulosa should be considered a separate species.

\section{Klossia pacbyleparon n. sp.}

Description of oocysts (fig. 6, 7). Oocysts spherical. Oocyst wall composed of 3 layers; a rough, dark brown outer layer $1 \mu \mathrm{m}$ thick, a yellowish middle layer $1 \mu \mathrm{m}$ thick and a colorless inner layer $0,5 \mu \mathrm{m}$ thick (verified by crushing oocysts). No micropyle. Twelve sporulated oocysts $29-40 \mu \mathrm{m}$ in diameter (33.6). Scattered oocyst residuum present. 

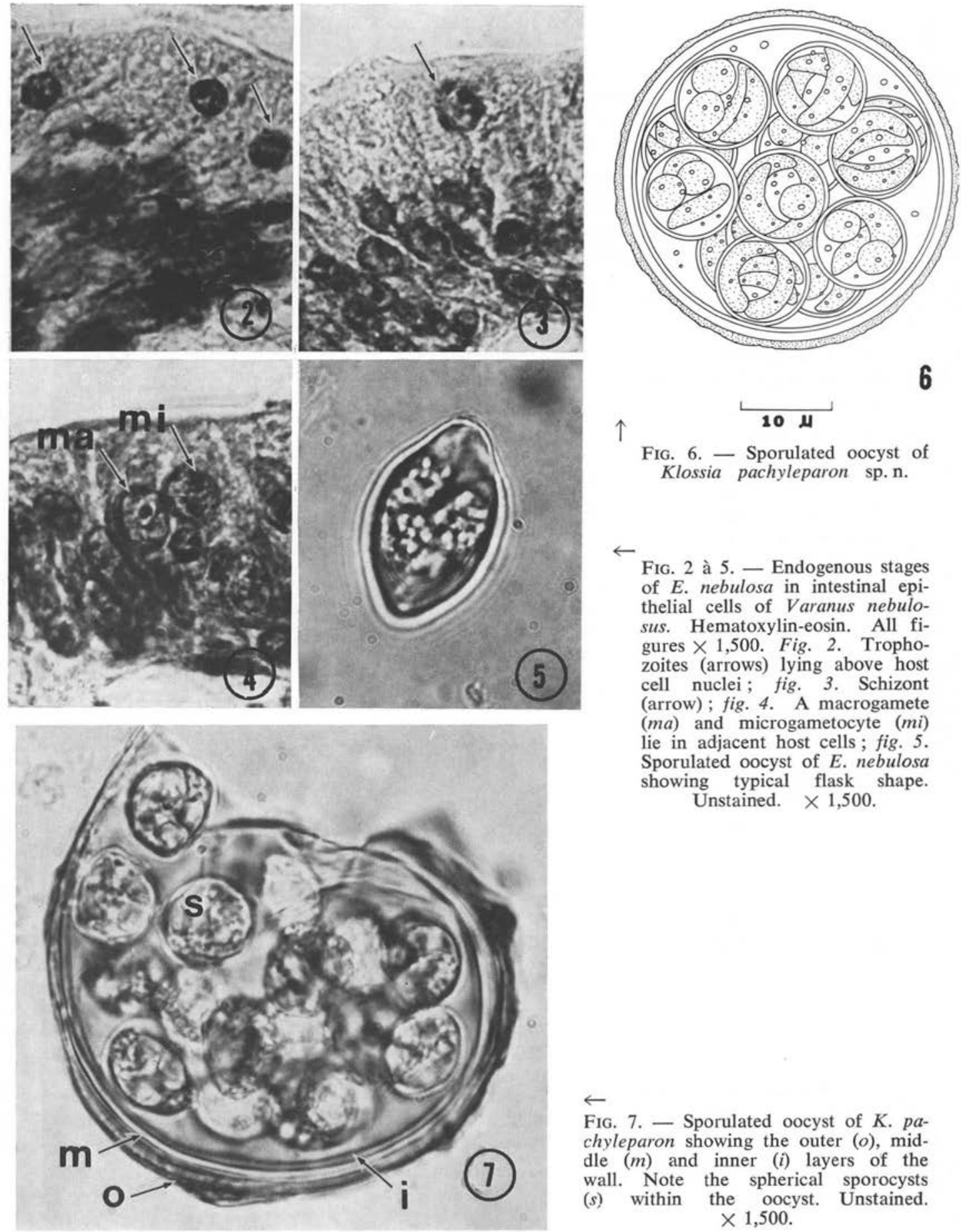

Fig. 7. - Sporulated oocyst of $K$. pachyleparon showing the outer (o), middle $(m)$ and inner $(i)$ layers of the wall. Note the spherical sporocysts $(s)$ within the oocyst. Unstained.

FIG. 2 à 5. - Endogenous stages thelial cells of Varanus nebulosus. Hematoxylin-eosin. All figures $\times 1,500$. Fig. 2. Trophozoites (arrows) lying above host cell nuclei; fig. 3. Schizont (arrow); fig. 4. A macrogamete (ma) and microgametocyte ( $m i)$ lie in adjacent host cells; fig. 5. Sporulated oocyst of E. nebulosa showing typical flask shape. Unstained. $\times 1,500$.

FIG. 6. - Sporulated oocyst of Klossia pachyleparon sp. $\mathrm{n}$.

(s) within the oocyst. Unstained. 
The oocyst is packed with sporocysts. Oocysts with $8,9,11,16,17$, and 18 sporocysts were observed. Twenty sporocysts $9-11 \mu \mathrm{m}$ in diameter (10.8). Scattered sporocyst residuum present. Each sporocyst has 4 sausage-shaped, curved sporozoites.

Remarks. Levine et al. (1955) described $K$. perplexans from a mouse deer and $K$. variablis from a bat in North America. The oocyst of $K$. pachyleparon differs from these in being spherical rather than ellipsoidal and in having 3 rather than 2 layers in the wall. Mullin and Colley (1972) reported Klossia sp. from a rat in Borneo. $K$. pachyleparon differs from this species in having a thick 3-layered wall rather than a membranous single-layered one.

To our knowledge Klossia has not been previously reported in a reptile. Most members of this genus have been reported as parasites of invertebrates and its presence in vertebrates may be spurious. Levine et al. (1955) discuss this possibility and review previous work on Klossia and related genera.

$K$. pachyleparon is the only Klossia species described to date which has a 3-layered oocyst wall. On this basis we feel that $K$. pachyleparon should be considered a separate species.

The name pachyleparon is Greek, meaning thick wall.

\section{Bibliography}

Bovee (E. C.) and Telford, Jr. (S. R.), 1965. - Eimeria sceloporis and Eimeria molochis spp. n. from lizards. J. Parasit., 51, 85-94.

Cannon (L. R. G.), 1967. - New coccidia from Australian lizards. II. Eimeria. Parasitology, $57,237-250$.

Knowles (R.) and Dasgupta (M.), 1935. - The coccidia of lizards. Indian J. Med. Res., 22, 701-707.

Levine (N. D.), Ivens (I.) and Kruidenier (F. J.), 1955. - Two new species of Klossia (Sporozoa: Adeleidae) from a mouse deer and a bat. J. Parasit., 41, 623-629.

Pellérdy (L. P.), 1965. - Coccidia and Coccidiosis. Akadémiai Kiadó (Publishing House of the Hungarian Academy of Sciences), Budapest.

Pellérdy (L. P.), 1969. - Katalog der Eimeriidea (Protozoa, Sporozoa) supplementum 1. Akadémiai Kiadó, Budapest. 